\title{
It's the ecology, stupid!
}

\author{
Can studies of environmental influences on developing organisms provide \\ the key to understanding the evolution of species and populations? \\ A growing number of researchers think so. Jennie Dusheck reports.
}

W e've seen evo-devo, now prepare for the next wave: eco-devo. Evolutionary developmental biologists have already made great strides in understanding how genes that direct the formation of body plans have influenced the evolution of major animal groups ${ }^{1}$. But organisms evolve in the context of their physical environments and of the other living things with which they interact. So biologists are now adding ecology to evodevo's blend of evolutionary biology, developmental biology and genetics.

"Eco-devo is a part of evo-devo that hasn't received its due," says Scott Gilbert of Swarthmore College in Pennsylvania. But since he coined the term 'ecological developmental biology' in a review article ${ }^{2}$ last year, the profile of this subdiscipline has been rising fast. "There has been a coalescing around the idea that we are going to integrate ecological context and development in a new way," says Sahotra Sarkar, a philosopher and historian of science at the University of Texas at Austin who studies trends in developmental biology.

Jessica Bolker, an evolutionary developmental biologist at the University of New Hampshire in Durham, attributes much of the upsurge in interest to Gilbert. "It's all Scott's fault," she jokes. "He's really excited about this, wants to push it, and is in a position to do so. He knows everybody."

A pivotal development came in January with a symposium on eco-devo, organized by Bolker and Gilbert, at the annual meeting of the Society for Integrative and Comparative Biology in Anaheim, California. Gilbert likens this gathering to the 1981 Dahlem Workshop on Evolution and Development in Berlin, which established baseline questions for the field of evo-devo. So what, in the light of the January symposium, is eco-devo all about?

Until now, explains Gilbert, evo-devo has focused primarily on mechanisms by which major taxonomic groups, such as phyla and classes, come into existence. But by considering development as a weaving together of genetic and environmental information to form a functioning organism, eco-devo will provide the detail explaining more about evolution at the levels of species and subpopulations.

A simplifying assumption of standard evolutionary theory is that genetic differ-
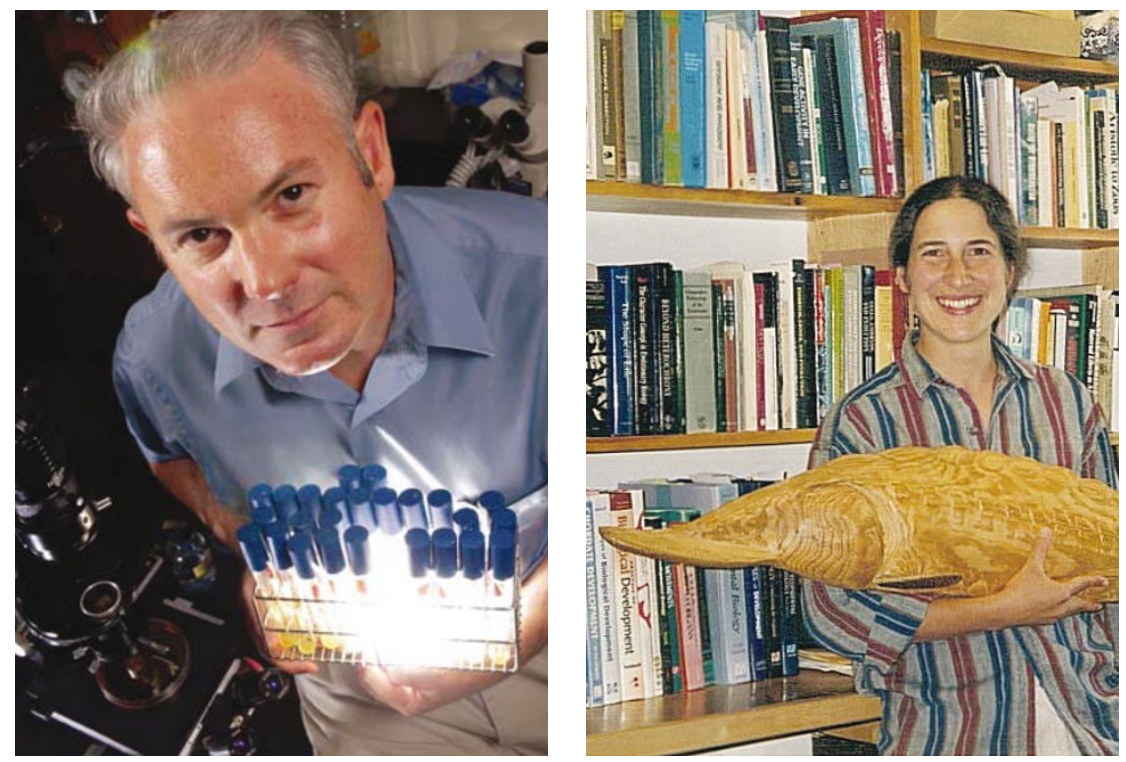

Champions of the cause: Scott Gilbert (left), who coined the term 'eco-devo', and Jessica Bolker, the idea's other strongest proponent, kickstarted the discipline at a landmark symposium in January.

ences determine the relative success or failure of organisms in a given environment. But in practice, many organisms can respond with considerable flexibility to a changing environment. Indeed, an overriding theme of eco-devo is phenotypic plasticity - the ability of a single set of genes to generate a range of characteristics, or phenotypes, depending on the environment in which the developing organism finds itself.

\section{Planting ideas}

To plant biologists, this is old news - amateur horticulturalists know that a cutting grown in moist conditions can look very different from a genetically identical cutting grown in dry soil. So the organizers of the January symposium made sure that plant biologists were invited. "Plant people are the ones who really do eco-devo," says Bolker.

Sonia Sultan of the Wesleyan University in Middletown, Connecticut, is one such researcher. She is interested in discovering, for example, whether generalist plants, which seem to survive well in a wide variety of environments, show greater plasticity than more specialized ones. She wants to know how plasticity relates to the diversification of closely related species, and whether plasticity can help to explain why some types of plant are likely to become weeds while others slide towards extinction.

At the Anaheim symposium, Sultan described her studies of four closely related species of buckwheat. The four differed in the extent and form of plasticity for a variety of traits, including root length and shape, the rate of photosynthesis and leaf size ${ }^{3}$. For example, the generalist species Polygonum persicaria reproduced more vigorously in resource-rich environments, and doubled its amount of leaf tissue in low light conditions. In contrast, Polygonum hydropiper, which grows only in sunny habitats with rich, wet soil, showed far less plasticity in these traits.

Nineteenth-century developmental biologists were aware that animals can show similar plasticity. But since then, the field has lost this perspective, partly through focusing on animals that share traits, such as rapid development, that tend to minimize the effects of the environment. So the view emerged that genes 'programme' development ${ }^{4}$. "Most of our models are small and fast and hard-wired, and so we think of development as being hard-wired," says Bolker. "But mice are not average mammals, Drosophila are not average insects, and Xenopus are weird frogs." 

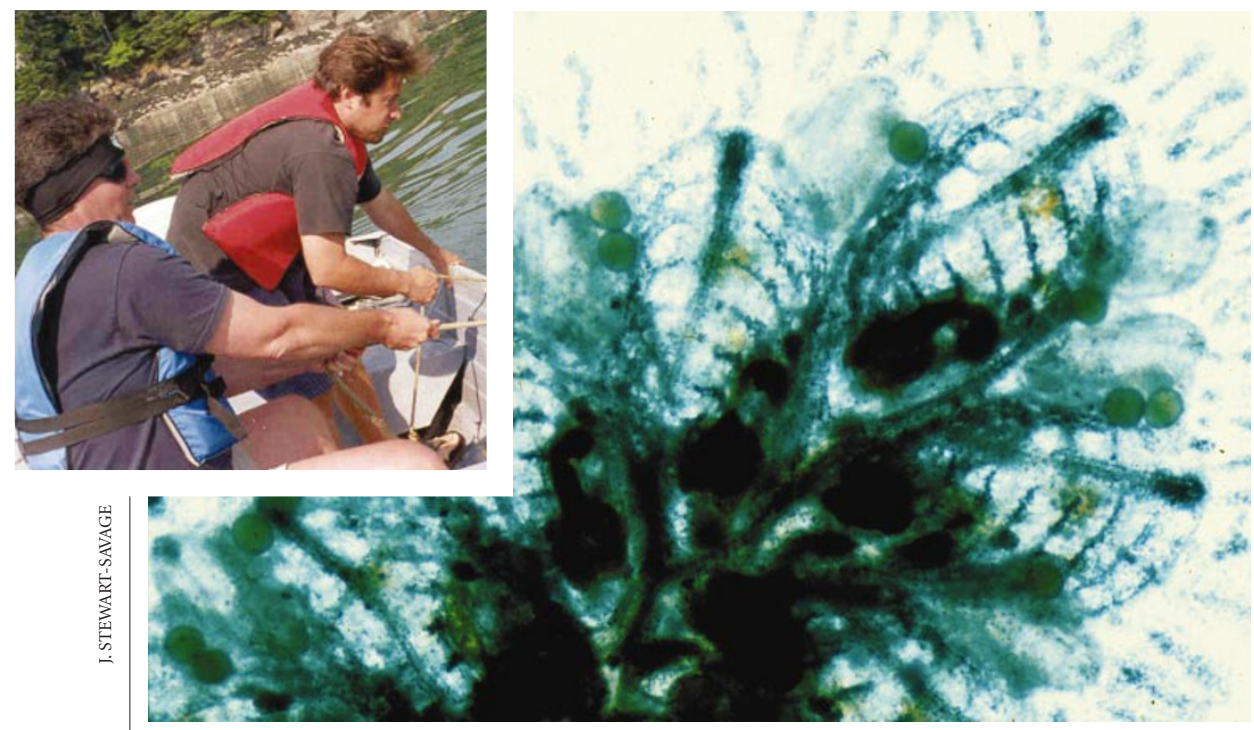

John Stewart-Savage (inset, right) has shown how nutrients affect reproduction in colonial sea squirts.
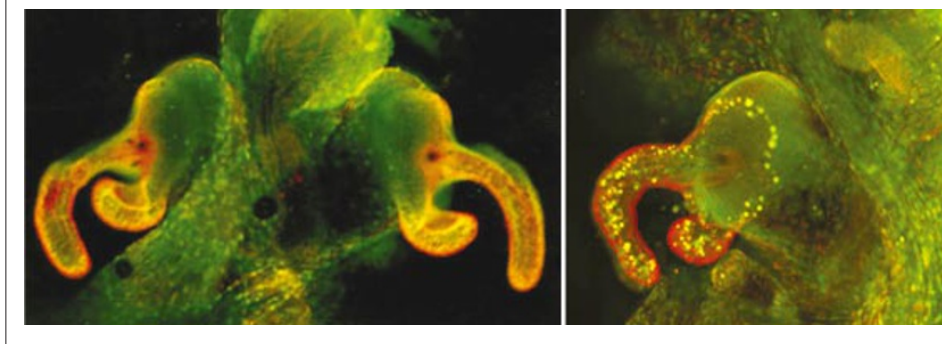

The bacterium Vibrio fischeri triggers maturation of the Hawaiian squid's light organ (above, right). Margaret McFall-Ngai has shown that cheating bugs can't do the same.

Some biologists are now staking out the territory of zoological eco-devo by studying different species. Developmental biologist John Stewart-Savage of the University of New Orleans, for instance, has teamed up with evolutionary ecologist Philip Yund of the University of Maine's Darling Marine Center in Walpole to study the heritability of reproductive effort in the colonial sea squirt Botryllus schlosseri. B. schlosseri is a cyclical hermophrodite, each individual within the colony alternating between making eggs and producing sperm.

Stewart-Savage and Yund took genetically identical sea squirts and placed them 10 kilometres apart in the estuary of Maine's Damariscotta River. At the upstream site - a warmer, more nutrient-rich environment individuals produced more eggs, whereas at the cooler, relatively nutrient-poor downstream site, individuals had larger testes ${ }^{5}$. This makes evolutionary sense: because eggs are more expensive to make, sperm production is favoured where nutrients are in short supply.

What was most striking, however, was that different genetic clones showed different degrees of plasticity. "There's a genetic basis for plasticity in reproductive effort," says Stewart-Savage. And that means that highly variable environments can select for greater plasticity, whereas those that are more stable select for low plasticity.

\section{Lighting the way}

Other organisms can be just as powerful as the physical environment in influencing development. One of the most dramatic examples is found in the Hawaiian squid Euprymna scolopes. In young squid, the light-emitting bacterium Vibrio fischeri-a relative of the microbe that causes cholera - guides the normal development of organs that house the bacteria and illuminate the lower surface of the squids' bodies. This prevents the animals from showing up as dark shapes when viewed from below by predators.

Once the bacteria infect immature light organs in juvenile squid, the organs' morphology develops over the ensuing four days through a process of bacteria-induced programmed cell death and cell swelling. But if young E. scolopes are never exposed to V. fischeri, these changes do not occur ${ }^{6}$. Researchers led by Margaret McFall-Ngai of the University of Hawaii have shown that the interaction is resistant to cheating by other bacteria looking for a comfortable home. Her team created two non-light-emitting $V$. fischeri mutants; neither was able to colonize the light organ ${ }^{7}$.
Bacteria also influence normal development in vertebrates. For example, DNAmicroarray comparisons of the activity of 25,000 genes from otherwise germ-free mice with and without the gut-living bacterium Bacteroides thetaiotaomicron have revealed marked changes in gene expression in the host gut when the bacterium is present $^{8}$. Some of the 100-plus genes involved are known to influence such tasks as nutrient absorption, blood-vessel formation and maturation of the intestine. This may help to explain why germ-free mice need around $30 \%$ more food than mice raised under normal conditions - particularly given that $B$. thetaiotaomicron is just one of hundreds of species that make up a healthy gut microbial flora.

Other living influences on development are rather larger. The presence of a waterborne chemical released by predatory dragonfly larvae, for instance, induces dramatic changes in the development of wood frog (Rana sylvatica) tadpoles. When tadpoles grow in water that has housed the predators, they develop bigger tails that allow for faster swimming and sharper turning ${ }^{9}$.

Bolker says that the blossoming of evodevo has awakened biologists to the importance of understanding developmental processes. "More people than just developmental biologists now know that development has implications for other fields," she says. And she suspects that increasing awareness of molecules in the environment that affect animals development - chemicals that mimic the sex hormone oestrogen, for example — should provide impetus to the newer subdiscipline of eco-devo.

Gilbert hopes to answer a range of fundamental questions for a multitude of different species. "Do organisms vary in how hardwired they are? What difference does that make? What are the genes that control plasticity? Can you select for plasticity?"

If the new practitioners of eco-devo can rise to the challenge of answering these questions, they could close the loop between ecology and evolution on the one hand, and genetics, cell biology and developmental biology on the other. "This is about how organisms do what ecologists know that they do," says Bolker.

Jennie Dusheck is a writer in Santa Cruz, California.

1. Arthur, W. Nature 415, 757-764 (2002).

2. Gilbert, S. Dev. Biol. 233, 1-12 (2001).

3. Sultan, S. E. Ecology 82, 328-343 (2001).

4. Bolker, J. BioEssays 17, 451-455 (1995).

5. Stewart-Savage, J., Sires, A. \& Yund, P. O. in Biology of Ascidians (eds Sawada, H., Yokosama, H. \& Lambert, C. C.) 311-314 (Springer, Tokyo, 2001).

6. McFall-Ngai, M. J. Dev. Biol. 242, 1-14 (2002)

Visick, K. L., Foster, J., Doino, J., McFall-Ngai, M. \& Ruby, E. G. J. Bacteriol. 182, 4578-4586 (2000)

8. Hooper, L. V. et al. Science 291, 881-884 (2001).

9. Van Buskirk, J. \& Relyea, R. A. Biol. J. Linn. Soc. 65 , 301-328 (1998). 